\title{
Changes in bacterioplankton metabolic capabilities along a salinity gradient in the York River estuary, Virginia, USA
}

\author{
Gary E. Schultz Jr${ }^{1}$, Hugh Ducklow ${ }^{2, *}$ \\ ${ }^{1}$ University of Houston, Dept of Biology and Biochemistry, 3201 Cullen Blvd., Houston, Texas 77204, USA \\ ${ }^{2}$ College of William and Mary, School of Marine Science, PO Box 1346, Gloucester Point, Virginia 23062, USA
}

\begin{abstract}
Changes in metabolic capabilities of bacterial communities along the estuarine salinity gradient may affect the extent of organic matter processing and bacterial growth and accumulation during transit through the system. As part of a larger study of estuarine microbial processes, we attempted to quantify differences in bacterial community structure using Biolog plates. Biolog GN plates (Biolog, Inc., Hayward, CA, USA) were used to determine differences in bacterioplankton community metabolic potential. Biolog GN microplates are 96-well microtiter plates in which each well contains an individual carbon source as well the redox dye tetrazolium violet. As bacteria grow and oxidize each substrate, a purple color is formed that can be quantified spectrophotometrically. The resultant patterns are a function of the original community inoculated into the sample wells. Samples were taken weekly from May 1997 through May 1998 at a fixed location. Samples were also collected bi-monthly from July 1997 through May 1998 at 6 stations located along the salinity gradient. Principal component analysis shows clear differences in the patterns of community metabolic capabilities along the salinity gradient. Bacterial communities were separated by both temperature and salinity. Rates of color development mimicked the pattern of a strong landward gradient in specific growth rates. Biolog analysis is shown to be a powerful tool for identifying shifts in bacterial community composition in space and time, and provides a useful guide for deeper analysis of bulk property data.
\end{abstract}

KEY WORDS: Bacterioplankton $\cdot$ Biolog $\cdot$ Community $\cdot$ Estuary

\section{INTRODUCTION}

Estuaries are typically regions of steep physical, biological and chemical gradients. Salinity may range from $0 \%$ to near marine salinities over short distances. Depending upon latitude, estuary temperatures may vary considerably on an annual basis. Estuaries are also greatly influenced by human activities. These activities may significantly change the organic matter loadings of an estuary over a short distance (Day et al. 1989). Physical factors such as wind and circulation are capable of changing estuarine conditions over a much smaller temporal scale than occurs in the open ocean.

*Corresponding author. E-mail: duck@vims.edu
These gradients may have a large effect on the composition of the bacterial community as it is carried from the upper reaches of the estuary out to the sea (Ketchum et al. 1952, Painchaud et al. 1996).

Due to these considerations and others, it is difficult to identify the factors that control bacterioplankton abundance and production in an estuary. There have been a number of studies that have attempted to determine these controls (e.g. Ducklow \& Kirchman 1983, Wright \& Coffin 1983, Coffin \& Sharp 1987, Wright et al. 1987, Findlay et al. 1991, Hoch \& Kirchman 1993, Shiah \& Ducklow 1994, 1995, Goosen et al. 1997). Some of these studies focused on a fixed location within the estuary; others collected data along a transect of the salinity gradient and lumped all the data 
together to perform data analyses. A few of the studies separated data by position or salinity, but these separations were made without regard to possible differences in microbial community structure. Not surprisingly, strong relationships, such as those seen between bacterial and primary production in the open ocean and in lakes (Fuhrman \& Azam 1980, Bird \& Kalff 1984, Lancelot \& Billen 1984, Cole et al. 1988, Currie 1990, White et al. 1991), are not seen in estuarine systems (Ducklow \& Kirchman 1983, Wright \& Coffin 1983, 1984, Painchaud \& Therriault 1989, Findlay et al. 1991, Ducklow \& Shiah 1993; but see Goosen et al. 1997). This lack of strong relationships could be due to differences in the metabolic capabilities of different bacterial communities encountered within the estuary in space and time. If one could distinguish between different microbial assemblages, data could possibly be stratified for analysis in a more insightful and informative manner.

Determining the types of bacteria that exist in any water sample is complicated by several factors. Marine bacteria are difficult to culture (Ferguson et al. 1984). Nucleic acid hybridization, or molecular probing, has been used to detect genes of specific bacterial metabolic potential in marine bacterial consortia without the need for cultivation (Barkay et al. 1989). However, this technique provides no information on whether the activity in question is actually occurring (Walia et al. 1990). Another molecular method that is useful in detecting organisms that are not culturable is polymerase chain reaction (PCR). PCR is used to amplify 16s rRNA sequences and then clone those sequences into vectors (DeLong et al. 1989, Giovannoni et al. 1990, Ward et al. 1990, Schmidt et al. 1991, Moyer et al. 1994, 1995). These methods provide a great deal of information on the phylogenetic diversity of a sample, but no information concerning the metabolic capabilities of the cells present. Lee \& Fuhrman (1990, 1991) used purified microbial community DNA to probe for similar sequences in the same and different environments. This gave them a quantitative measure of the relative similarity between populations. However, this method, like the other molecular methods discussed above, is very time consuming. The effort and cost required to process samples limit the appeal of these methods.

In the late 1980s, Biolog, Inc. (Hayward, CA, USA) developed a technique to test bacterial isolates for strain identification using sole carbon source utilization. Biolog chose 95 different carbon substrates, based on their ability to distinguish between clinically important species (Bochner 1989). Although the Biolog technique was developed for use in clinical microbiology, Garland \& Mills (1991) used Biolog plates to differentiate between bacterial communities in a marsh creek and in an ocean inlet. Since that time, several other investigators have used Biolog plates to characterize environmental communities. Studies have been performed on soil communities (Garland \& Mills 1991, Bossio \& Scow 1995, England et al. 1995, Haack et al. 1995, Vahjen et al. 1995, Wunsche et al. 1995, Knight et al. 1997), plant leaves (Harvey \& Miller 1996), tree and crop rhizospheres (Garland \& Mills 1991, Garland 1996), compost (Insam et al. 1996), wastewater (Guckert et al. 1996, Victorio et al. 1996) as well as marine bacterioplankton (Jellet et al. 1996). These studies have generated a great deal of controversy over the use of these plates to provide answers to fundamental questions of microbial diversity (Konopka et al. 1998).

Konopka et al. (1998) raised several valid points. Color development in the wells does not occur until a density of approximately $10^{8}$ cells $\mathrm{ml}^{-1}$ is reached. Since cell density in natural samples is typically much less than this, this technique must be regarded as a culture-based method. In addition, the substrates in the wells may not be the substrates found in the environment from which the sample was taken. Thus, the results cannot be used to determine the makeup of the original community, or the metabolic 'fingerprint' of the original community. The pattern that results from inoculation of the wells, however, must be a function of the original community. Thus, even critics of Biolog plates concede that the plates can be used to characterize environmental samples that differ from each other in their response patterns (Konopka et al. 1998). We believe that prudent use of the information obtained from analysis of Biolog plates used with samples from the natural environment may be valuable in determining the factors that separate microbial communities. This information may be especially valuable to stratify data in meaningful ways such that patterns and relationships in large data sets may be discovered.

The purpose of our study was to use Biolog plates to distinguish between the metabolic potential of different bacteria communities in an estuary in space and time and to determine the environmental factors that control the separation of communities. Data were then stratified by community to focus further data analysis.

\section{MATERIALS AND METHODS}

Sampling. York River transect samples: Samples were collected bi-monthly from July 1997 to May 1998 at 6 stations along the salinity gradient of the York River estuary (Fig. 1). Stations were approximately $9 \mathrm{~km}$ apart with Stn 1 located at the mouth of the York River and Stn 6 located in freshwater in the Pamunkey River approximately $60 \mathrm{~km}$ from the mouth. Samples 


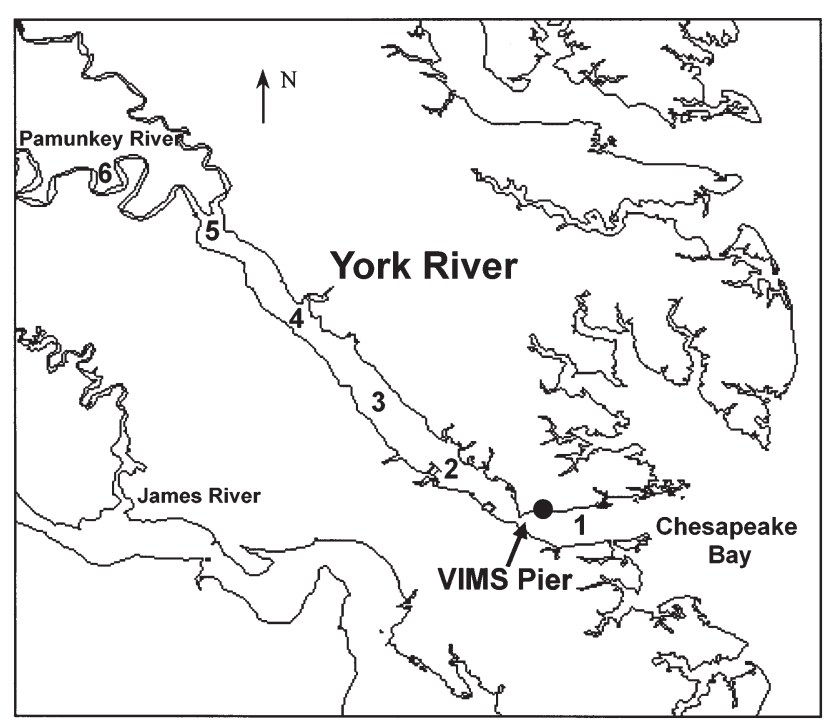

Fig. 1. Map of site locations (Stns 1 to 6) and the Virginia Institute of Marine Science (VIMS) pier. York River estuary, Virginia, USA

were collected $1 \mathrm{~m}$ below the surface at each station using a clean 2.51 Niskin bottle. Approximately $750 \mathrm{ml}$ were transferred to a clean 11 polycarbonate bottle. Samples were kept in the dark and were brought back to the lab at in situ temperatures. These samples were collected as part of a larger study on bacterioplankton dynamics (Schultz \& Ducklow unpubl.). Water temperature and salinity were measured. Bacterial abundance and biovolume were measured by epifluorescent microscopy and image analysis of cells stained with acridine orange (Shiah \& Ducklow 1995). Bacterial production was estimated from [ ${ }^{3} \mathrm{H}$-methyl]-thymidine $\left({ }^{3} \mathrm{H}-\mathrm{TdR}\right)$ incorporation and average cell biovolume for each sample using appropriate conversion factors (Ducklow \& Carlson 1992, Shiah \& Ducklow 1995). A measure of specific growth rate was obtained by dividing production by biomass. Chlorophyll a (chl a) was determined fluorometrically by DMSO/acetone extraction according to Burnison (1980). Water was also collected for determination of dissolved organic carbon (DOC), dissolved organic nitrogen (DON), dissolved oxygen (DO) and nutrients $\left(\mathrm{NH}_{4}\right.$, TDN [total dissolved nitrogen], $\mathrm{NO}_{2}$ and $\mathrm{NO}_{3}$ ).

Pier samples: Samples were collected from the York River weekly from May 1997 to May 1998 from the Virginia Institute of Marine Science (VIMS) ferry pier located on the VIMS campus (Fig. 1). Samples were collected $1 \mathrm{~m}$ below the surface with a clean 11 polycarbonate bottle. Samples were analyzed for bacterial cell abundance, bacterial activity and chl a. Biolog plates were immediately inoculated with sample in the lab.
Biolog plates. Biolog GN plates were used to determine differences in bacterioplankton community metabolic potential. Biolog GN microplates (Biolog, Inc.) are 96-well microtiter plates containing 95 carbon sources. These sources are supplied in each well in a dried-film form (Bochner 1989). Each well also contains the redox dye tetrazolium violet. As bacteria grow and oxidize each substrate, reduced nicotinamide adenine dinucleotide (NADH) is formed. The tetrazolium violet dye functions as a substitute electron acceptor during this biochemical oxidation (Siedler 1991). The reduced product is a colored, insoluble formazan seen as a purple color that is quantified spectrophotometrically. The 96th well is a control that contains tetrazolium dye only. It is assumed that the resultant pattern occurring on the Biolog plate is a function of the original community inoculated into the sample wells.

All samples were transferred from the 11 sample bottles to the Biolog plates using an 8-channel multipipette. Care was taken not to touch the interior of the wells to prevent cross-contaminating substrates, and tips were discarded between plates to prevent crosscontamination of plates. Due to a problem with condensation forming inside the plate tops, $125 \mu \mathrm{l}$ of sample were transferred to each well rather than the manufacturers' recommended $150 \mu \mathrm{l}$. Immediately upon inoculation, the zero time-point absorbance of each plate was read before incubating the samples at their in situ temperature.

Changes in color development were measured using a single-channel automated spectrophotometric microplate reader $(E L \times 800$; BIO-TEK Instruments, Inc., Winooski, Vermont, USA) at a wavelength of $590 \mathrm{~nm}$. Plates were measured approximately every 6 to $24 \mathrm{~h}$ for changes in color development until maximum color development was reached. Maximum color development took from $72 \mathrm{~h}$ post-inoculation in warm water months to as long as $240 \mathrm{~h}$ post-inoculation in cold water months.

Overall color development for each plate was expressed as average well color development (AWCD) after Garland \& Mills (1991). AWCD $=\sum[(R-C) / 95]$, where $R$ is the absorbance of each response well, and $C$ is the absorbance of the control well. Garland \& Mills (1991) suggested using a standard AWCD to eliminate biases caused by differences in initial cell abundance per well. Since color development follows a sigmoidal curve with incubation time, an AWCD value in the middle of the linear phase would give the greatest difference in substrate utilization patterns. Therefore, the measured sample with AWCD closest to $0.5( \pm 0.2)$ was used in all cases.

To reduce the influence of rate of color development among the plates, the absorbance value for each well was transformed according to Garland \& Mills (1991) 
by subtracting the absorbance of the control well from the absorbance of each well and dividing by the AWCD. Negative responses were set to zero before analysis.

Hierarchical cluster analysis. Hierarchical cluster analysis (HCA) was used to determine differences between patterns of substrate utilization with the Ein*Sight v 4.0 software package (InfoMetrix Corp.). The data were assembled into a large matrix. Each sample was placed into one of $n$ rows with $p$ columns of variables, in this case the absorbance measurements. The samples were treated as $n$ points in a $p$-dimensional space. HCA groups data into clusters with similar attributes by determining the relative distances between pairs of samples in data space (Lebart et al. 1984). Euclidian distance and centroidal clustering were used in this analysis. When distances were relatively small, the samples were assumed to be similar with respect to the measured variables. Data from HCA were used to construct a dendrogram (Fig. 2). Each of the branches on the far left is called a leaf (see Fig. 2). The shorter the leaf, the greater the similarity and, therefore, the smaller the distance between the samples. Similarity was measured from 0.0 to 1.0 , with 1.0 corresponding to an exact duplicate and 0.0 indicating maximum relative dissimilarity within the data set.

Principal components analysis. Principal components analysis (PCA) was used to determine differences between patterns of the substrate utilization profiles. Again, the software package Ein*Sight v 4.0 was used to perform PCA. To compare Biolog plates, the samples must be compared with the 95 variables. PCA is an exploratory tool, useful for reducing the number of variables in a given data matrix by collapsing the dimensionality of the data. This is accomplished by projecting the original data onto new axes, or principal components (PCs) (Lebart et al. 1984). These PCs are ranked according to the amount of the variance of the original sample that is accounted for by each PC. PC1 accounts for most of the variance, PC2 accounts for the next greatest amount of variance and so on. Basically, the farther apart 2 samples are in their original (95-dimensional) space, the farther apart they will be in 2-dimensional space. This allows the use of PCA to observe relationships between samples by plotting the scores of their PCs in 2 or more dimensions. Since the first 2 PCs account for the greatest amount of variance in the samples, they are typically the scores that are plotted.

\section{RESULTS}

\section{Patterns of sole carbon source utilization}

VIMS pier

Hierarchical cluster analysis: HCA was performed on the transformed Biolog data collected from the ferry pier to group the data by similarity. The data



Fig. 2. Results of hierarchical cluster analysis (HCA) on Biolog results obtained for samples collected at the VIMS pier. Each leaf (left of figure) is labeled by season, date (mo/d/yr) and temperature. Season is indicated by $\mathrm{S}=$ spring (March, April, May), Su = summer (June, July, August), $\mathrm{F}=$ fall (September, October, November) and $\mathrm{W}=$ winter (December, January, February). Numbers at the top of the figure indicate percent similarity between paired samples. Samples labeled Su8/26/97-26.7a and $\mathrm{b}$ are machine replicates. Samples labeled Su6/10/97-19.8a, b and c, and F10/14/97-22.6a and b are sampling replicates 
separated into 2 main clusters (Fig. 2). Temperature was the most obvious difference between the 2 clusters. The upper leaves were all samples with water temperature less than $21^{\circ} \mathrm{C}$ (except for 1 sample on September 9, 1997) while the lower leaves were mostly (14 of 19) samples from water temperatures greater than $21^{\circ} \mathrm{C}$. Similarly, 2 clusters were also separated by season. Spring and winter samples (March, April, May and December, January, February respectively) were concentrated in the upper group, while summer and fall samples (June, July, August and September, October, November respectively) were concentrated in the lower group.

Sample variability was tested in 3 ways. The same samples were run twice throughout the incubation to test for variability in the spectrophotometer's reading. The similarity between these samples was very close to 1.0 (Fig. 2; August 26, 1997). On June 10, 1997, 3 samples were taken from the same 11 bottle and incubated together. These samples were grouped by HCA with a similarity $>0.6$ (Fig. 2). Finally, 2 samples were collected in 2 separate 11 bottles on October 14, 1997. These samples were also grouped together at a similarity of $\sim 0.6$ (Fig. 2). Together, these results suggest that focus should be concentrated on samples with less than $60 \%$ similarity.

Principal components analysis: PCA was performed on the 46 transformed Biolog data sets from the VIMS pier near the mouth of the York River. The samples showed a distinct separation by temperature along the first PC (Fig. 3). PC1 was positive for samples taken when the temperature was $>21^{\circ} \mathrm{C}$ and negative for samples taken when the temperature was $<21^{\circ} \mathrm{C}$. Temperature was positively related to PC1 scores $\left(\mathrm{r}^{2}=0.58\right.$;

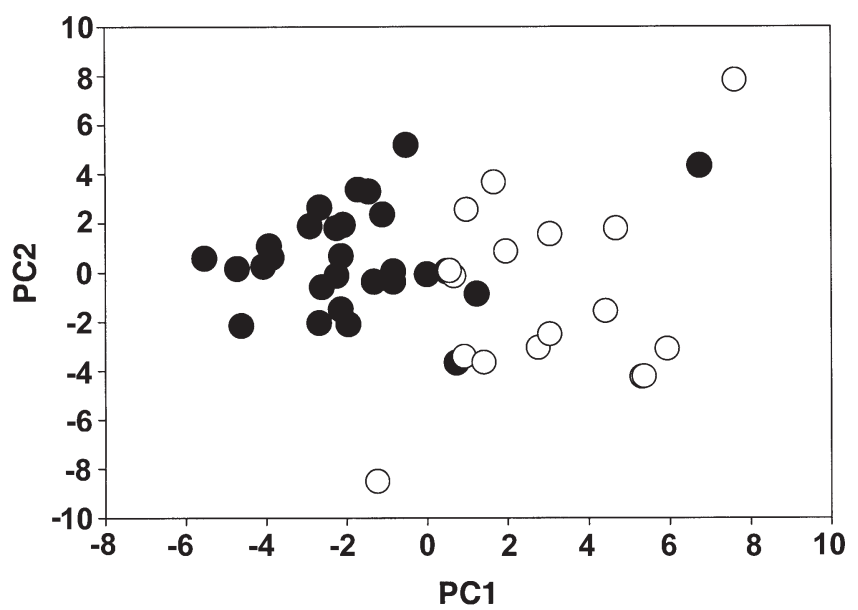

Fig. 3. Score plot for principal components PC1 and PC2 from principal components analysis of Biolog data obtained from samples collected at the VIMS ferry pier. Samples are labeled according to temperature. (O) Samples collected when temperature $>21^{\circ} \mathrm{C}$. (@) Samples collected when temperature $<21^{\circ} \mathrm{C}$ $\mathrm{p}<0.0001$ ) but was not significantly related to PC2, and the spread along PC2 was about the same for both temperature groups. Nearly $60 \%$ of the variance was accounted for in the first 10 PCs, with PC1 accounting for $11.2 \%$ and PC2 accounting for $8.9 \%$. The small amount of variation accounted for by each individual PC was due to the high dimensionality (95) of the original data set.

Salinity also affected the separation of samples. From May 1997 to May 1998, the salinity at the VIMS pier ranged from 10 to $23.1 \%$ (VIMS Scientific Data Archive at http://www.vims.edu/data_archive/pier/). Salinity was not related to PC1, but was negatively related to the scores of PC2 $\left(\mathrm{r}^{2}=0.33 ; \mathrm{p}<0.0001\right)$. Thus, samples with high salinity values $(>12 \%$ ) were relatively lower along the PC2 axis than samples with lower salinity values.

\section{York River transect}

Hierarchical cluster analysis: HCA separated the data from the York River transect into 5 distinct clusters ( 1 of the 5 is a lone station) (Fig. 4). Of the 17 members of the first cluster (A), only 3 had salinities $>10 \%$. These 3 included 2 anomalous samples from Stn 5, which has a salinity $\sim 5 \%$ over most of the year. The other sample (Stn 1 with salinity $\sim 12 \%$ ) was also anomalous since Stn 1 typically has a salinity $>18 \%$. The second cluster (B) in Fig. 4 comprised only Stn 6 from September 1997. This was a time of low freshwater flow when the salinity at the normally freshwater Stn 6 was $>3 \%$. The third cluster (C) was composed of Stns 1, 2, 3 and 4 during 1 sampling period (July 1997). The fourth cluster (D) had 9 samples from November and January and 1 sample from March, and all but 1 sample had salinities greater than $10 \%$. The last cluster (E) was made up of samples from Stns 1, 2, 3, and 4 during September 1997.

The 2 clusters that were most dissimilar (similarity $\approx$ 0.0 ), were also split by salinity. In the upper cluster, 15 of the 22 members had salinity $<10 \%$. The lower cluster had 14 members with only 1 having a salinity $<10 \%$.

Principal components analysis: PCA was performed on the bi-monthly samples from the 6 stations along the salinity gradient of the York River (Fig. 5). The first 12 PCs accounted for more than $70 \%$ of the variance in the data, with PC1 accounting for $16.2 \%$ and PC2 accounting for $10.6 \%$. Although there was much overlap, distinct patterns were present in the PCA of the station data (Fig. 5). The spread of the data seemed to indicate a general progression from Stn 1 scores in the upper left quadrant to Stn 6 scores in the lower right quadrant. 


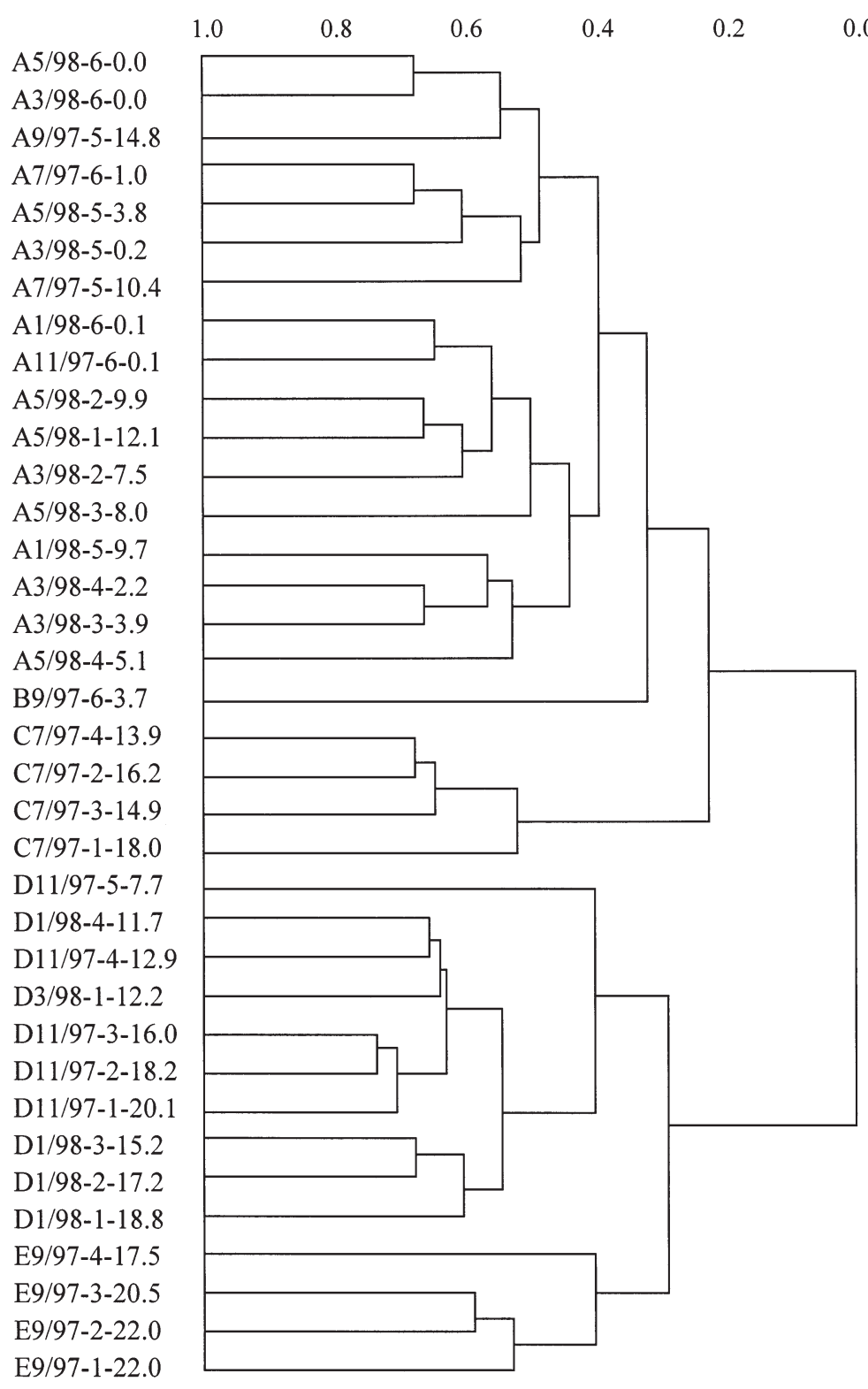

Fig. 4. HCA results for Biolog data obtained for York River transect samples. Leaves are labeled by date, station number, and then salinity. The initial letter identifies the 5 groupings discussed in the 'Results'
0.0 examination of Fig. 5 with this information showed a distinct separation of the data points by temperature (Fig. 6). Points from samples with temperatures above $21^{\circ} \mathrm{C}$ were generally located above and to the right of those with temperatures below $21^{\circ} \mathrm{C}$. Samples were also separated by salinity (Fig. 7). Points from samples with salinity greater than $12 \%$ were generally above and to the left of those with salinity less than $12 \%$.

To relate the utilization of individual carbon substrates to the differences in the sole carbon source utilization patterns, the correlation between the substrate variables and the PCs (Table 1) was examined. The higher the correlation, the more important that substrate was for differentiating between samples. A high correlation does not imply that the carbon source was well utilized. A high correlation simply means that the difference in the utilization of that carbon source was highest between samples. Samples with higher PC1 scores showed a higher response to those carbon sources positively correlated to PC1 than samples with lower PC1 scores. For these data, the substrates that were most important in differentiating between sole carbon source utilization were those which explained $>25 \%$ of the variance in the data $(-0.5>\mathrm{r}>$ 0.5, using Pearson's product moment regression). This $r$ is not very large, but no single variable explained more than $43 \%$ of the variance in this set of data.

By examining Fig. 5 and Table 1, carbon substrates that were most important in differentiating between bacterial communities in the York River can be determined. In general, Stn 1 had the lowest PC1 values. This indicates that the bacterial community at Stn 1 utilized the substrates that were positively correlated to PC1 relatively less than did the bacterial community at Stn 6 .

To determine the factors with the greatest influence on pattern development, multiple factor linear regressions were performed between all parameters measured (temperature, salinity, bacterial cell abundance, bacterial activity, chl $a, \mathrm{DOC}, \mathrm{DON}, \mathrm{DO}, \mathrm{NH}_{4}, \mathrm{TDN}$, $\mathrm{NO}_{2}$ and $\mathrm{NO}_{3}$ ) and the scores of the PCs. Temperature and salinity were the only 2 parameters with a significant relationship with the scores of the PCs. Temperature and salinity together accounted for approximately $63 \%$ of the variance in PC1 ( $\mathrm{p}<0.0001)$ and approximately $68 \%$ of the variance in PC2 (p < 0.0001). Re-
These substrates were comprised of several classes of substrates including carboxylic acids ( $\gamma$-hydroxybutyric acid, D-galacturonic acid, $\beta$-hydroxybutyric acid, and D-saccharic acid), an aromatic acid (urocanic acid), carbohydrates (m-inositol, D-psicose, and D-melibiose), 2 amines (2-amino ethanol, and putrescine), and amino acids (D,L-carnitine, L-pyroglutamic acid, L-phenylalanine, L-leucine, and hydroxy L-proline). Lower PC1 values at Stn 1 also indicate that the bacterial community there uses relatively more of the substrates that were negatively correlated to $\mathrm{PC} 1$ with respect to 


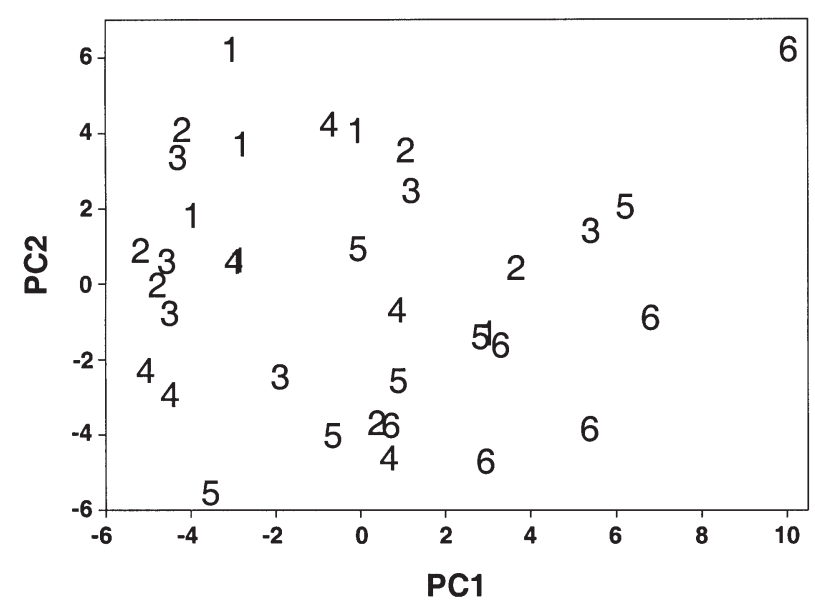

Fig. 5. PC1 plotted against PC2 for the Biolog data collected from the sites along the length of the York River, July 1997 to May 1998. Numbers indicate the station number for each of the 6 mo sampled

Stn 6. These substrates included 2 carboxylic acids (Dgluconic acid, and D,L-lactic acid), 2 carbohydrates (cellobiose, and D-mannitol), 3 amino acids (glycyl-Lglutamic acid, and L-alanyl-glycine) and 2 polymers (glycogen and $\alpha$-cyclodextrin).

Stn 1 had generally higher PC2 values than did Stn 6 . For the substrates that were positively correlated to $\mathrm{PC}$, this indicates that the bacterial community at Stn 1 used relatively more of these substrates than did the community at Stn 6 . The substrates that correlated with $\mathrm{PC} 2$ with a variance of $-0.5>\mathrm{r}>0.5$ included several carboxylic acids $(\alpha$-ketovaleric acid, acetic acid, $\alpha$ ketoglutaric acid, and propionic acid), 2 aromatic compounds (thymidine and uridine), carbohydrates (lactulose, xylitol, and adonitol), and 2 amino acids (Lproline, L-threonine). There were also 3 carboxylic acids (quinic acid, D-saccharic acid, and p-hydroxyphenylacetic acid) and 2 carbohydrates ( $\alpha$-D-glucose and sucrose) that exhibited a negative correlation with PC2. This indicates that the bacterial community at Stn 1 used relatively less of these substrates than did the community at Stn 6.

\section{Changes in plate color development over time}

Plate color development was measured every $24 \mathrm{~h}$. The change in color development is similar in appearance to a growth curve. To obtain the overall rate of color development, the total color development $\left(\sum R=\right.$ TCD) was exchanged for bacterial cell number in the growth equation: $\ln \left(N_{t}\right)-\ln \left(N_{\mathrm{o}}\right)=k t$ to obtain: $\ln \left(\mathrm{TCD}_{t}\right)-\ln \left(\mathrm{TCD}_{\mathrm{o}}\right)=k t_{\text {, where }} N_{t}=$ cell number at time $t, N_{\mathrm{o}}=$ cell number of original population, and $k=$

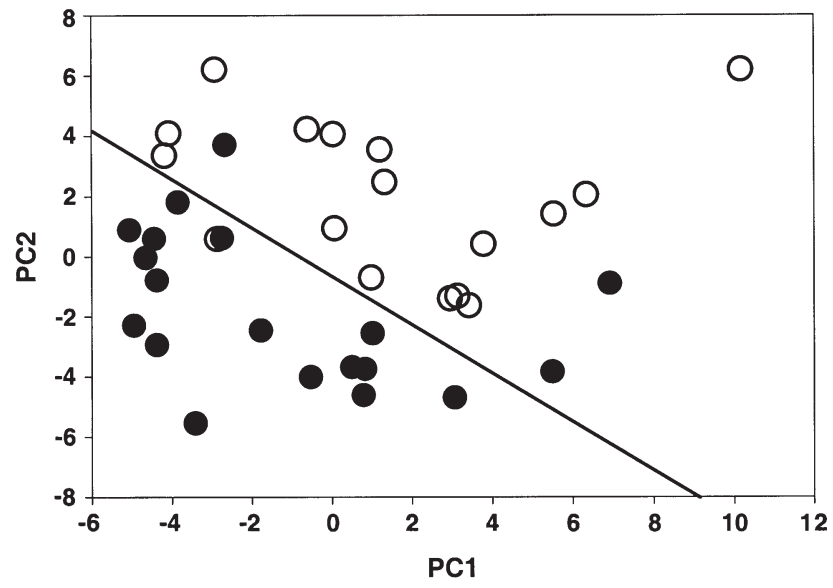

Fig. 6. Score plot of PC1 against PC2 of Biolog data obtained from water samples collected bi-monthly along the length of the York River, July 1997 to May 1998. Samples are labeled by temperature. (O) Samples collected when temperature $>21^{\circ} \mathrm{C}$. (-) Samples collected when temperature $<21^{\circ} \mathrm{C}$. The line was drawn by eye to suggest a general separation of data

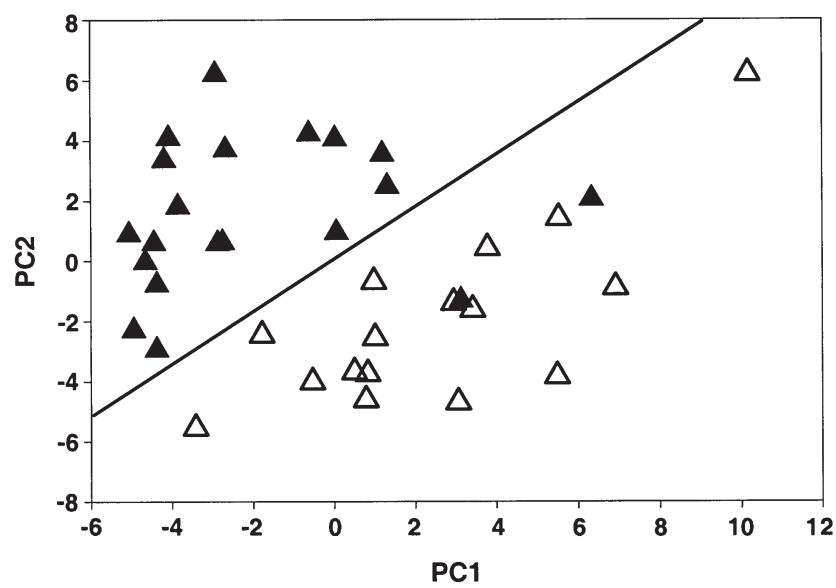

Fig. 7. Score plot of PC1 against PC2 of Biolog data obtained from water samples collected bi-monthly along the length of the York River, July 1997 to May 1998. Samples are labeled by salinity. $(\Delta)$ Samples collected when salinity $<12 \%$. ( $(\Delta)$ Samples collected when salinity $>12 \%$. The line was drawn by eye to suggest a general separation of data

specific growth rate constant. This gives a rate of color change analogous to specific growth rate. This equation was applied to all the samples for the York River cruises. Rates for total color development were compared to growth rates obtained from measurements of bacterial cell abundance and incorporation of ${ }^{3} \mathrm{H}$-TDR (Table 2). This comparison was not meant to show that the change in TCD was equal to growth rates, but that the rate of color development showed the same pattern as growth rates along the river. Indeed, as seen in Table 2, growth rates typically follow the same pattern as rate of color development over every sampling 
Table 1. Correlation coefficient for scores of the first 2 principal components (PC1 and PC2) from the York River data collected at Stns 1 to 6 and the transformed measured absorbance for each substrate. All substrates with an $r>0.5$ are shown $(p<0.005)$. r: Pearson's correlation coefficient

\begin{tabular}{|lrlr|}
\hline PC1 & & PC2 & \\
Substrate name & $\mathrm{r}$ & Substrate name & $\mathrm{r}$ \\
\hline D,L-carnitine & 0.763 & Alpha-keto valeric acid & 0.663 \\
D-galacturonic acid & 0.720 & Lactulose & 0.654 \\
$\beta$-hydroxybutyric acid & 0.718 & Acetic acid & 0.581 \\
L-pyroglutamic acid & 0.692 & Thymidine & 0.565 \\
2-amino ethanol & 0.683 & Alpha-keto glutanic acid & 0.557 \\
Putrescine & 0.665 & L-proline & 0.556 \\
Urocanic acid & 0.636 & Propionic acid & 0.529 \\
m-inositol & 0.629 & Uridine & 0.522 \\
$\gamma$-hydroxybutyric acid & 0.579 & Xylitol & 0.521 \\
L-phenylalanine & 0.556 & Adonitol & 0.521 \\
L-leucine & 0.534 & L-threonine & 0.506 \\
D-saccharic acid & 0.528 & Quinic acid & -0.671 \\
D-psicose & 0.518 & $\alpha$-D-glucose & -0.624 \\
D-melibiose & 0.509 & Sucrose & -0.571 \\
Hydroxy L-proline & 0.500 & D-saccharic acid & -0.572 \\
Glycogen & -0.697 & $p$-hydroxy phenylacetic acid & -0.559 \\
Glycyl-L-glutamic acid & -0.665 & & \\
$\alpha$-cyclodextrin & -0.633 & & \\
D-gluconic acid & -0.619 & & \\
Cellobiose & -0.610 & & \\
L-alanyl-glycine & -0.563 & & \\
D,L-lactic acid & -0.557 & & \\
D-mannitol & -0.515 & & \\
L-threonine & -0.514 & & \\
& & & \\
\hline
\end{tabular}

selective subset of the entire population. Also, as stated earlier, the substrates included in the Biolog plates are not necessarily representative of the substrates available in the natural environment (Konopka et al. 1998). Konopka et al. (1998) clearly summarized these and other concerns regarding the use of Biolog with natural samples. Therefore, attempting to use Biolog plates to characterize the 'functional diversity' of microbial communities (Zak et al. 1994) may not be prudent.

Biolog plates, however, may still be useful for use with environmental samples. Konopka et al. (1998) conceded that Biolog plates can distinguish between different communities in natural samples. Several investigators have successfully used Biolog plates to differentiate between microbial communities (Garland \& Mills 1991, Zak et al. 1994, Bossio \& Scow 1995, Garland 1996, Grayson \& Campbell 1996, Guckert et al. 1996, Harvey \& Miller 1996, Insam et al. 1996, and Victorio et al. 1996). Carbon substrate utilization patterns may also be

period. Growth rate (as measured by ${ }^{3} \mathrm{H}-\mathrm{TdR}$ incorporation) and rate of color development were positively and significantly correlated in every month sampled ( $\mathrm{r}=0.85, \mathrm{p}<0.01$ in July 1997; $\mathrm{r}=0.95, \mathrm{p}<0.001$ in September 1997; $\mathrm{r}=0.67, \mathrm{p}<0.1$ in November 1997; $\mathrm{r}$ $=0.71, \mathrm{p}<0.05$ in January 1998; $\mathrm{r}=0.90, \mathrm{p}<0.05$ in March 1998; $r=0.94, p<0.002$ in May 1998). They were both relatively low at Stn 1 and they increased with distance upstream to Stn 6. Thus, it appears as though general conclusions on the relative magnitude of growth rates are consistent with the rate of change of color development in Biolog plates. However, due to the unrealistic substrate concentrations (Konopka 1998) and other concerns, care should be used when making these types of comparisons.

\section{DISCUSSION}

There are several concerns regarding the use of Biolog plates with natural samples. Haack et al. (1995) found that cell density in each well must reach $10^{8}$ $\mathrm{ml}^{-1}$ before color development is observed. Most natural environments, including estuaries, have cell densities far below $10^{8} \mathrm{ml}^{-1}$. Thus, Biolog plates are an enrichment culture and the inoculum will grow a used to identify ecologically relevant bacteria isolated from environmental samples. McCarthy \& Murray (1996) used Biolog plates on 103 Gram-negative isolates cultured from a contaminated aquifer. They were able to tentatively identify 55 of the isolates and kept records of the carbon source utilization pattern of the remaining 48 isolates for future characterization.

Another potentially important use for Biolog plates is in substrate addition studies or other studies requiring long incubations. Bacterial population composition may shift during long incubations (Suzuki 1998) causing misleading results. Biolog plates may be quickly and cheaply used to determine if bacterial communities have changed over the course of incubation.

Finally, by separating different communities, Biolog plates can be used to gain insight into bulk measurements of bacterial properties. Knowing that there are different microbial assemblages in space and/or time may allow the investigator to stratify data such that more information may be extracted.

Shiah \& Ducklow (1995) found that temperature plays a strong role in controlling estuarine bacterial dynamics. Therefore, to ensure that bacterial activity is not stimulated or retarded relative to their natural environment, our samples were incubated at in situ 
Table 2. Temperature, salinity, chl $a$, cell abundance, specific growth rate and rate of change in total color development ( $\Delta$ TCD) for each station over the course of the sampling period (July 1997 to May 1998). Growth rates are derived from incorporation of ${ }^{3} \mathrm{H}$-thymidine measurements and abundances. Change in TCD is the maximum $24 \mathrm{~h}$ change over the length of the incubation

\begin{tabular}{|c|c|c|c|c|c|c|c|}
\hline Date & Stn & $\begin{array}{l}\text { Temp. } \\
\left({ }^{\circ} \mathrm{C}\right)\end{array}$ & $\begin{array}{c}\text { Salinity } \\
(\% \circ)\end{array}$ & $\begin{array}{c}\text { Chl a } \\
\left(\mu g l^{-1}\right)\end{array}$ & $\begin{array}{c}\text { Abundance } \\
\left(\times 10^{9} \text { cells }^{-1}\right)\end{array}$ & $\begin{array}{l}\text { Growth rate } \\
\qquad\left(\mathrm{d}^{-1}\right)\end{array}$ & $\begin{array}{c}\Delta \mathrm{TCD} \\
\left(\mathrm{d}^{-1}\right)\end{array}$ \\
\hline Jul 1997 & 1 & 26.3 & 18.0 & 34.2 & 6.8 & 0.6 & 2.1 \\
\hline Jul 1997 & 2 & 26.5 & 16.2 & 63.7 & 5.1 & 1.3 & 1.4 \\
\hline Jul 1997 & 3 & 27.5 & 14.9 & 45.2 & 4.8 & 1.5 & 2.1 \\
\hline Jul 1997 & 4 & 27.8 & 13.9 & 85.8 & 4.2 & 2.8 & 2.3 \\
\hline Jul 1997 & 5 & 28.0 & 10.4 & 75.4 & 7.9 & 2.2 & 3.7 \\
\hline Jul 1997 & 6 & 28.7 & 1.0 & 46.2 & 2.4 & 5.4 & 5.0 \\
\hline Sep 1997 & 1 & 24.0 & 22.6 & 47.6 & 5.2 & 1.5 & 0.4 \\
\hline Sep 1997 & 2 & 24.3 & 22.1 & 51.4 & 2.6 & 3.5 & 0.4 \\
\hline Sep 1997 & 3 & 24.2 & 20.5 & 47.6 & 2.1 & 4.7 & 0.5 \\
\hline Sep 1997 & 4 & 24.2 & 17.5 & 86.2 & 2.6 & 4.9 & 0.6 \\
\hline Sep 1997 & 5 & 24.2 & 14.8 & 85.8 & 2.0 & 7.1 & 0.8 \\
\hline Sep 1997 & 6 & 24.6 & 3.7 & 91.6 & 2.5 & 8.2 & 0.9 \\
\hline Nov 1997 & 1 & 8.9 & 20.1 & 3.2 & 2.3 & 0.6 & 0.2 \\
\hline Nov 1997 & 2 & 8.3 & 18.2 & 4.7 & 1.6 & 1.0 & 0.3 \\
\hline Nov 1997 & 3 & 8.2 & 16.0 & 6.2 & 1.4 & 1.4 & 0.3 \\
\hline Nov 1997 & 4 & 8.0 & 13.0 & 8.0 & 1.4 & 1.7 & 0.5 \\
\hline Nov 1997 & 5 & 8.3 & 7.7 & 13.2 & 2.3 & 1.6 & 0.7 \\
\hline Nov 1997 & 6 & 8.2 & 0.1 & 3.6 & 1.3 & 7.0 & 0.7 \\
\hline Jan 1998 & 1 & 6.1 & 18.8 & 12.0 & 2.6 & 0.4 & 0.1 \\
\hline Jan 1998 & 2 & 6.4 & 17.2 & 14.9 & 2.2 & 0.6 & 0.2 \\
\hline Jan 1998 & 3 & 6.5 & 15.2 & 29.3 & 2.5 & 0.5 & 0.1 \\
\hline Jan 1998 & 4 & 6.4 & 11.7 & 17.8 & 1.6 & 1.1 & 0.3 \\
\hline Jan 1998 & 5 & 6.6 & 9.7 & 11.7 & 1.7 & 0.3 & 0.4 \\
\hline Jan 1998 & 6 & 6.6 & 0.1 & 3.4 & 2.4 & 1.6 & 0.6 \\
\hline Mar 1998 & 1 & 13.5 & 12.2 & 23.7 & 3.3 & 3.3 & 0.8 \\
\hline Mar 1998 & 2 & 15.0 & 7.5 & 10.5 & 3.7 & 3.7 & 0.7 \\
\hline Mar 1998 & 3 & 15.7 & 3.9 & 7.4 & 2.6 & 4.2 & 0.9 \\
\hline Mar 1998 & 4 & 16.9 & 2.2 & 6.4 & 2.5 & 5.7 & 0.9 \\
\hline Mar 1998 & 5 & 17.1 & 0.1 & 6.9 & 2.4 & 10.3 & 1.0 \\
\hline Mar 1998 & 6 & 17.5 & 0.0 & 6.4 & 2.5 & 11.4 & 1.1 \\
\hline May 1998 & 1 & 22.1 & 12.1 & 9.1 & 6.9 & 0.8 & 0.6 \\
\hline May 1998 & 2 & 21.6 & 9.9 & 15.7 & 6.7 & 1.8 & 0.6 \\
\hline May 1998 & 3 & 22.3 & 8.0 & 36.5 & 5.5 & 2.6 & 0.6 \\
\hline May 1998 & 4 & 21.7 & 5.1 & 33.7 & 4.0 & 4.4 & 1.0 \\
\hline May 1998 & 5 & 21.2 & 3.8 & 17.7 & 3.7 & 4.6 & 1.2 \\
\hline May 1998 & 6 & 20.7 & 0.0 & 13.9 & 1.9 & 19.9 & 1.9 \\
\hline
\end{tabular}

temperatures. PCA and HCA of the patterns of carbon substrate utilization separated the microbial assemblage of the York River estuary into 4 communities (Fig. 8). These analyses showed that communities within the York River differed both by temperature and by salinity. Two points should be emphasized here. One is that the 4 communities may or may not be separated by assemblages of species. The purple color quantified in analysis of Biolog plates is due to bacterial oxidation of the substrate. If a species of bacteria is unable to utilize the substrate, due to environmental factors such as extreme temperature or salinity, that species will not reduce the tetrazolium dye and will not add to the measured absorbance of the well. Thus, depending on the environment at the time of collection, a species may be present but not accounted for in the pattern seen on plates. The second point to be made is that, although temperature and salinity separate these communities, these factors may not directly control the bacterial community. Instead, temperature and salinity may foster conditions that indirectly influence the structure of the bacterial community (i.e. primary production).

Perhaps the most valuable use for Biolog plates is to use the groupings identified by the plates to stratify data sets. Stratification of bulk data as suggested by analysis of Biolog plates may also allow investigators to focus on relationships between bacteria and environmental factors that might otherwise be missed. Correlations run on the entire data set collected by Schultz \& Ducklow (unpubl.) show no significant relationships between bacterial abundance and temperature, TdR incorporation, or chl a. Significant relationships are seen, however, when the data are stratified (Table 3). 


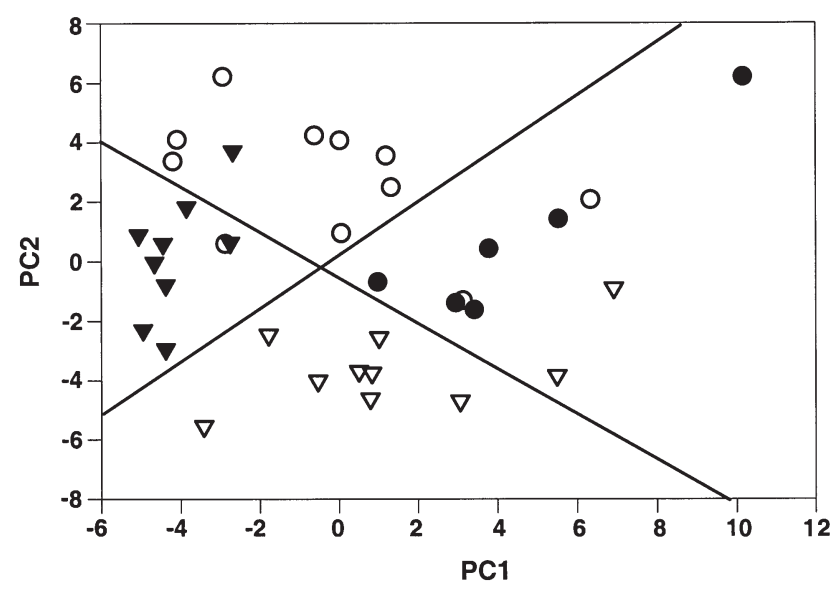

Fig. 8. Score plot of PC1 against PC2 of Biolog data obtained from water samples collected bi-monthly along the length of the York River, May 1997 to May 1998. (O) Samples collected when temperature $>21^{\circ} \mathrm{C}$ and salinity $>12 \%$. (@) Samples collected when temperature $>21^{\circ} \mathrm{C}$ and salinity $<12 \%$. $(\Delta)$ Samples collected when temperature $<21^{\circ} \mathrm{C}$ and salinity $<12 \%$. ( $\Delta$ ) Samples collected when temperature $<21^{\circ} \mathrm{C}$ and salinity $>12 \%$. Lines were drawn by eye to suggest a general separation of data

Table 3. Results of Model I regressions (r) between bacterial abundance, bacterial activity $\left({ }^{3} \mathrm{H}-\mathrm{TdR}\right.$ incorporation), temperature, and chl $a$ in the 4 bacterial communities of the York River as identified by Biolog plates. Community I has temperature $<21^{\circ} \mathrm{C}$ and salinity $<12 \%$, $\mathrm{n}=42$; Community II has temperature $>21^{\circ} \mathrm{C}$ and salinity $<12 \%, \mathrm{n}=21$; Community III has temperature $<21^{\circ} \mathrm{C}$ and salinity $>12 \%$, $\mathrm{n}=25$; Community IV has temperature $>21^{\circ} \mathrm{C}$ and salinity $>12 \%$, $\mathrm{n}=20$. Data from all 18 cruises were included (Schultz \& Ducklow unpubl.). Numbers in bold identify significant relationships $(p<0.01)$

\begin{tabular}{|lcccc|}
\hline & Abundance & Activity & Temp. & Chl $a$ \\
\hline Community I & & & & \\
Abundance & - & 0.03 & 0.36 & 0.32 \\
Activity & 0.03 & - & $\mathbf{0 . 5 5}$ & -0.16 \\
Temp. & 0.36 & $\mathbf{0 . 5 5}$ & - & 0.08 \\
Chl $a$ & 0.32 & -0.10 & 0.08 & - \\
Community II & & & & \\
Abundance & - & -0.20 & 0.15 & -0.18 \\
Activity & -0.20 & - & -0.02 & $\mathbf{0 . 6 8}$ \\
Temp. & 0.15 & -0.02 & - & 0.22 \\
Chl $a$ & -0.18 & $\mathbf{0 . 6 8}$ & 0.22 & - \\
Community III & & & & \\
Abundance & - & 0.10 & $\mathbf{0 . 7 7}$ & 0.16 \\
Activity & 0.10 & - & 0.38 & 0.17 \\
Temp. & $\mathbf{0 . 7 7}$ & 0.38 & - & 0.00 \\
Chl $a$ & 0.16 & 0.17 & 0.00 & - \\
Community IV & & & & \\
Abundance & - & $-\mathbf{0 . 6 2}$ & -0.14 & $-\mathbf{0 . 6 7}$ \\
Activity & $-\mathbf{0 . 6 2}$ & - & 0.13 & $\mathbf{0 . 6 9}$ \\
Temp. & -0.14 & 0.13 & - & 0.33 \\
Chl $a$ & $-\mathbf{0 . 6 7}$ & $\mathbf{0 . 6 9}$ & 0.33 & - \\
& & & & \\
\hline
\end{tabular}

Stratifying data based on carbon substrate utilization also reduces the risk of auto-correlation with the factors that most strongly influence the separation of communities. In this study, salinity and temperature were the only 2 environmental factors found to separate the bacterial communities. Since many of the environmental parameters may be strongly influenced by salinity and temperature, the risk of autocorrelation is great. Examining the data by community reduces the influence of temperature and salinity and allows determination of the environmental parameters that affect bacterial dynamics within each community. For example, using all the unstratified data collected, bacterial abundance is not significantly related to chl $a$, but is significantly related to temperature. If the data are stratified as indicated by the PCA, bacterial abundance is significantly related to temperature only in Community III when salinity is greater than $12 \%$ and temperature is less than $21^{\circ} \mathrm{C}$ (Table 3). Bacterial abundance and chl a are significantly and negatively related only where salinity is greater than $12 \%$ and temperature is greater than $21^{\circ} \mathrm{C}$ (Community IV) (Table 3 ). Since abundance and temperature are not significantly related in this community, this cannot be an auto-correlation. This may indicate that bacteria in the higher salinity region of the York River may be more dependent upon phytoplankton as their carbon source than the bacteria in low salinity region of the York River. This suggestion agrees with the conclusions generated by Schultz \& Ducklow (unpubl.).

Biolog plates are not capable of determining the species composition of a natural sample and cannot identify the types of substrates utilized by a bacterial community in their natural environment (Konopka et al. 1998), but as has been demonstrated here, they are useful in differentiating between microbial communities and in determining the factors that most influence the separation of these communities. Knowing where these separations occur in natural systems may prove to be invaluable in determining how best to stratify measurements of bulk bacterial properties and environmental parameters for analysis. The relative low cost (US $\$ 5.44$ per plate as of June 2000) and ease of use makes these sole carbon source utilization plates an attractive addition to any study of bacterial dynamics conducted in a natural system over space and/or time.

Acknowledgements. We thank Bob Gammish and Charles Machen for piloting the RV 'Kingfisher' on sampling trips. We also thank Flynn Cunningham, Matt Church, Pete Countway, Leigh McCallister and Helen Quinby for helping with sample collection. Support for this study was received from the Office of Naval Resources (contract number N00014-93-1-0986). 


\section{LITERATURE CITED}

Barkay T, Liebert C, Gillman M (1989) Hybridization of DNA probes with whole community genome for detection of genes that encode microbial responses to pollutants: mer genes and $\mathrm{Hg}^{2+}$ resistance. Appl Environ Microbiol 55: $1574-1577$

Bird DF, Kalff J (1984) Empirical relationships between bacterial abundance and chlorophyll concentration in fresh and marine waters. Can J Fish Aquat Sci 41: 1015-1023

Bochner B (1989) 'Breathprints' at the microbial level. Am Soc Microbiol News 55:536-539

Bossio DA, Scow KM (1995) Impact of carbon flooding on the metabolic diversity of microbial communities in soils. Appl Environ Microbiol 61:4043-4050

Burnison BK (1980) Modified dimethyl sulfoxide (DMSO) extraction for chlorophyll analysis of phytoplankton. Can J Fish Aquat Sci 37:729-733

Coffin RB, Sharp JH (1987) Microbial trophodynamics in the Delaware Estuary. Mar Ecol Prog Ser 41:253-266

Cole JJ, Findlay S, Pace ML (1988) Bacterial production in fresh and saltwater ecosystems: a cross-system overview. Mar Ecol Prog Ser 43:1-10

Currie DJ (1990) Large-scale variability and interactions among phytoplankton, bacterioplankton and phosphorous. Limnol Oceanogr 35:1437-1455

Day JW Jr, Hall CAS, Kemp WM, Yanez-Arancibia A (1989) Estuarine ecology. John Wiley \& Sons, New York

DeLong EF, Wickham GS, Pace NR (1989) Phylogenetic stains: ribosomal RNA-based probes for the identification of single cells. Science 243:1360-1363

Ducklow HW, Carlson CA (1992) Oceanic bacterial production. In: Marshall KC (ed) Advances in microbial ecology, Vol 12. Plenum Publishing Corporation, New York, p 113-181

Ducklow HW, Kirchman DL (1983) Bacterial dynamics and distribution during a spring bloom in the Hudson River plume, USA. J Plankton Res 5:333-355

Ducklow HW, Shiah FK (1993) Bacterial production in estuaries. In: Ford TE (ed) Aquatic microbiology: an ecological approach. Blackwell Scientific Publications, Oxford, p 261-287

England HS, Lee H, Trevors JT (1995) Recombinant and wildtype Pseudomonas aureofaciens strains introduced into soil microcosms: effect on decomposition of cellulose and straw. Mol Ecol 4:221-230

Ferguson RL, Buckley EN, Palumbo AV (1984) Response of marine bacterioplankton to differential filtration and confinement. Appl Environ Microbiol 47:49-55

Findlay S, Pace ML, Lints D, Cole J, Caraco NF, Peierls B (1991) Weak coupling of bacterial and algal production in a heterotrophic ecosystem: the Hudson River estuary. Limnol Oceanogr 36(2):268-278

Fuhrman JA, Azam F (1980) Bacterioplankton secondary production estimates for coastal waters of British Columbia, Antarctica, and California. Appl Environ Microbiol 39: 1085-1095

Garland JL (1996) Patterns of potential C source utilization by rhizosphere communities. Soil Biol Biochem 28:223-230

Garland JL, Mills AL (1991) Classification and characterization of heterotrophic microbial communities on the basis of patterns of community-level sole-carbon-source utilization. Appl Environ Microbiol 57:2351-2359

Giovannoni SJ, Britschgi TB, Moyer CL, Field KG (1990) Genetic diversity in Sargasso Sea bacterioplankton. Nature 345:60-63

Goosen NK, van Rijswijk P, Kromkamp J, Peene J (1997) Reg- ulation of annual variation in heterotrophic bacterial production in the Schelde estuary (SW Netherlands). Aquat Microb Ecol 12:223-232

Grayson SJ, Campbell CD (1996) Functional biodiversity of microbial communities in the rhizospheres of hybrid larch (Larix eurolepis) and Sitka spruce (Picea Sitchensis). Tree Physiol 16:1031-1038

Guckert JB, Carr GJ, Johnson TD, Hamm BG, Davidson DH, Kumagai Y (1996) Community analysis by Biolog: curve integration for statistical analysis of activated sludge microbial habitats. J Microbiol Methods 27:183-197

Haack SK, Garchow J, Klug MJ, Forney LJ (1995) Analysis of factors affecting the accuracy, reproducibility and interpretation of microbial community carbon source utilization patterns. Appl Environ Microbiol 61:1458-1468

Harvey E, Miller TE (1996) Variance in composition of inquiline communities in leaves of Sarracenia purpurea L on multiple spatial scales. Oecologia 108:562-566

Hoch MP, Kirchman DL (1993) Seasonal and inter-annual variability in bacterial production and biomass in a temperate estuary Mar Ecol Prog Ser 98:283-295

Insam H, Amor K, Renner M, Crepaz C (1996) Changes in functional abilities of the microbial community during composting of manure. Microb Ecol 31:77-87

Jellett JF, Li WKW, Dickie PM, Boraie A, Kepkay PE (1996) Metabolic activity of bacterioplankton communities assessed by flow cytometry and single carbon substrate utilization. Mar Ecol Prog Ser 136:213-225

Ketchum BH, Ayers JC, Vaccaro RF (1952) Processes contributing to the decrease of coliform bacteria in a tidal estuary. Ecology 33:247-258

Knight BP, McGrath SP, Chaudri AM (1997) Biomass carbon measurements and substrate utilization patterns of microbial populations of soils amended with cadmium, copper, or zinc. Appl Environ Microbiol 63:39-43

Konopka A, Oliver L, Turco RF Jr (1998) The use of carbon substrate utilization patterns in environmental and ecological microbiology. Microb Ecol 35:103-115

Lancelot C, Billen G (1984) Activity of heterotrophic bacteria and its coupling to primary production during spring phytoplankton bloom in the southern bight of the North Sea. Limnol Oceanogr 29:721-730

Lebart L, Morineau A, Warwick KM (1984) Multivariate descriptive statistical analysis. John Wiley \& Sons, New York

Lee S, Fuhrman J (1990) DNA hybridization to compare species compositions of natural bacterioplankton assemblages. Appl Environ Microbiol 56:739-746

Lee S, Fuhrman J (1991) Spatial and temporal variation of natural bacterioplankton assemblages studied by total genomic DNA cross-hybridization Limnol Oceanogr 36: $1277-1287$

McCarthy CM, Murray L (1996) Viability and metabolic features of bacteria indigenous to a contaminated deep aquifer. Microb Ecol 32:305-321

Moyer CF, Dobbs F, Karl D (1994) Estimation of diversity and community structure through restriction fragment length polymorphism distribution analysis of bacterial 16S rRNA genes from a microbial mat at an active, hydrothermal vent system, Loihi Seamount, Hawaii. Appl Environ Microbiol 60:871-879

Moyer CF, Dobbs F, Karl D (1995) Phylogenetic diversity of the bacterial community from a microbial mat at an active, hydrothermal vent system, Loihi Seamount, Hawaii. Appl Environ Microbiol 61:1555-1562

Painchaud J, Therriault JC (1989) Relationships between bacteria, phytoplankton and particulate organic carbon in 
the upper St. Lawrence estuary. Mar Ecol Prog Ser 56: 301-311

Painchaud J, Lefaivre D, Therriault JC, Legendre L (1996) Bacterial dynamics in the upper St Lawrence estuary. Limnol Oceanogr 41:1610-1618

Schmidt TM, DeLong EF, Pace NR (1991) Analysis of a marine picoplankton community by $16 \mathrm{~S}$ rRNA gene cloning and sequencing. J Bacteriol 173:4371-4378

Shiah FK, Ducklow HW (1994) Temperature and substrate regulation of bacterial abundance, production and specific growth rate in Chesapeake Bay, USA. Mar Ecol Prog Ser 103:297-308

Shiah FK, Ducklow HW (1995) Multiscale variability in bacterioplankton abundance, production, and specific growth rate in a temperate salt-marsh tidal creek. Limnol Oceanogr 40(1): 55-66

Siedler E (1991) The tetrazolium-formazan system: design and histochemistry. Prog Histochem Cytochem 24:1-86

Suzuki MT (1998) The effect of protistan bacterivory on bacterioplankton diversity. $\mathrm{PhD}$ thesis, Oregon State University, Corvalis, OR

Vahjen W, Munch JC, Tebbe CC (1995) Carbon source utilization of soil extracted microorganisms as a tool to detect the effects of soil supplemented with genetically engineered and non-engineered Corynebacterium glutamicum and a recombinant peptide at the community level. FEMS Microbiol Ecol 18:317-328

Victorio L, Gilbride KA, Allen DG, Liss SN (1996) Phenotypic fingerprinting of microbial communities in wastewater treatment systems. Water Resour 30:1077-1086

Walia S, Khan A, Rosenthal N (1990) Construction and application of DNA probes for detection of polychlorinated

Editorial responsibility: John Dolan, Edgewater, Maryland, USA biphenyl-degrading genotypes in toxic organic-contaminated soil environments. Appl Environ Microbiol 56: 254-259

Ward DM, Weller R, Bateson M (1990) 16S rDNA sequences reveal numerous uncultured organisms in a natural community. Nature 345:63-65

White P, Kalff J, Rasmussen J, Gasol J (1991) The effect of temperature and algal biomass on bacterial production and specific growth rate in freshwater and marine habitats. Microb Ecol 21:99-118

Wright RT, Coffin RB (1983) Planktonic bacteria in estuaries and coastal waters of northern Massachusetts: spatial and temporal distribution. Mar Ecol Prog Ser 11:205-216

Wright RT, Coffin RB (1984) Factors affecting bacterioplankton density and productivity in salt marsh estuaries. In: Klug MJ, Reddy CA (eds) Proceedings of the 3rd International Symposium on Microbial Ecology. American Society for Microbiology, Michigan State University, p 485-494

Ward DM, Weller R, Bateson M (1990) 16S rRNA sequences reveal numerous uncultured organisms in a natural community. Nature 345:63-65

Wright RT, Coffin RB, Lebo ME (1987) Dynamics of planktonic bacteria and heterotrophic microflagellates in the Parker Estuary, northern Massachusetts. Cont Shelf Res 7: 1383-1397

Wunsche L, Bruggemann L, Babel W (1995) Determination of substrate utilization patterns of soil microbial communities: an approach to assess population changes after hydrocarbon pollution. FEMS Microbiol Ecol 17:295-306

Zak JC, Willig MR, Moorhead DL, Wildman HG (1994) Functional diversity of microbial communities: a quantitative approach. Soil Biol Biochem 26:1101-1108

Submitted: January 9, 2000; Accepted: July 5, 2000

Proofs received from author(s): August 23, 2000 